\title{
Proceeding
}

Supplementary Issue: Winter Conferences of Sports Science. International Conference on Psychology of Education Sciences and Lifestyle.

\section{Distinguished leadership behaviours and styles of basketball coaches in UAE universities}

\author{
MAJED SALEEM EL-SALEH , MOHANNAD MOHAMMAD ALTHAWABEYEH \\ College of Education, Humanities and Social Sciences, Al Ain University, United Arab Emirates
}

\begin{abstract}
This study aims to identify the distinguished leadership behaviours and styles of basketball teams' coaches in UAE universities. The researchers have adopted a descriptive method through using surveying methodology, which suites the nature of the study. The sample of the study consists of 60 male and female players of the university teams participating in the Abu Dhabi Inter-University Sports League (ADISL) for the 2018/2019 sports season, who have been randomly selected. They all responded to the modified Scale Assessing Leadership Behaviour of Coaches, used by Mustafa Abu Zeid (1999), which consists of 55 paragraphs. After collecting the data and conducting the necessary statistical processes, the researchers have concluded that the leadership behaviour of basketball coaches in UAE universities changes in training and matches in contrast with the Scale dimensions. They have also concluded that attention to health aspects, athletic performance, and social as well as democratic recognition are the most common and most common methods used by the coaches. In light of the findings, the researchers have recommended that coaches should use the democratic style of leadership due to its appropriateness for the nature of players' way of thinking in universities, avoid the dictatorial leadership style and pay heed to motivation and equity among players. The researchers also recommend that the study findings should be generalized to the Higher Education Sports Federation (HESF) and the UAE Basketball Association, conduct similar studies for coaches of other games and organize training courses for university coaches on the most important and new methods of sports training and leadership.

Keywords: Leadership behaviour; Leadership styles; Coaches; University teams; Players; Basketball.
\end{abstract}

\section{Cite this article as:}

El-Saleh, M.S., \& Althawabeyeh, M.M. (2020). Distinguished leadership behaviours and styles of basketball coaches in UAE universities. Journal of Human Sport and Exercise, 15(2proc), S393-S407. doi:https://doi.org/10.14198/jhse.2020.15.Proc2.30

Corresponding author. College of Education, Humanities and Social Sciences, Al Ain University, United Arab Emirates.

E-mail: majed.elsaleh@aau.ac.ae

Supplementary Issue: Winter Conferences of Sports Science. International Conference on Psychology of Education Sciences and Lifestyle.

JOURNAL OF HUMAN SPORT \& EXERCISE ISSN 1988-5202

(c) Faculty of Education. University of Alicante

doi:10.14198/jhse.2020.15.Proc2.30 


\section{INTRODUCTION}

A coach's personality relies on pedagogical athletic behaviour and style; it holds pedagogical, educational, and administrative roles that effectively influence the comprehensive and balanced development of an athlete's personality inside and outside the court. Hence, the personal characteristics of coaches play a significant role in achieving the desired goal and tasks. Moreover, it has become inevitable that a successful coach should have his personality as a field leader. For this reason, as a leader, a successful coach is expected to provide his team with vision and to know well how to turn such a future vision into a reality that enables every athlete to achieve maximum success. It is necessary for a coach, in his or her turn, to take on a role in preparing the psychological atmosphere of the team members and not to limit its role to developing the physical abilities and skills (Rateb, 1995). This is because the coach's leadership behaviour acts as the linchpin of all the games due to its significance in influencing the players' behaviours, which, in turn, affect the players as to how to find the propitious and productive atmosphere that constitutes right continuation, and whose positive or negative impact upon the results achieved by the players during the training or competition is reflected.

Consequently, coaches shoulder the responsibility for understanding a player's behaviour, dealing with it, and attempting to find explanations for the dimensions implied by that behaviour. A coach's leadership behaviour influences how to identify the player's behaviour, instruct the player and, thus motivate him/her and improve his/her efficiency to achieve the desired performance and results in the competitions, particularly university championships.

\section{PROBLEM AND SIGNIFICANCE OF THE STUDY}

Leadership is one of the significant elements in influencing others' behaviours and dedicating their energy to optimum use in order to achieve the group's objectives. When we realize that one style or another is unable to achieve its objectives effectively, a particular problem comes to our minds, which is how players respond to their coaches, whose leadership styles are different, and what their behaviours towards their coaches are alike. This is where the problem of the study arises, through the observations of the researchers, being skilful at basketball and a coach in university teams, that there is disparity in the players' results achieved in university championships, and through observing the various and several styles of their fellow coaches; such styles lack the practical guidance and leadership of coaching. The significance of the current study is made clear by studying coaches from the players' perspective, and for the two sexes, as a scholarly and practical influential value and a focal point for the team to reach the highest levels, achieve the best performance, reach the desired positions for their students and players at the university level through their experiences and behavioural style followed with different UAE university teams.

\section{Objectives of the study}

The study aims at:

Identifying the leadership behaviour and style of basketball coaches in the UAE universities for the 2018/2019 university sports season.

\section{Questions of the study}

What is the leadership behaviour or style of basket coaches in the UAE universities from the perspective of the participating players? 


\section{Domains of the study}

Human Domain

Male and female players of the UAE basketball university teams for the 2018/2019 sports season.

Space Domain

The HESF Championship of the UAE universities for basketball, held in Abu Dhabi emirate (ADISL) for the 2018/2019 sports season.

Time Domain

From 29/10/2018 until 1/4/2019.

\section{METHODOLOGY AND FIELD PROCEDURES}

\section{Methodology}

The researchers have adopted a descriptive method through surveying methodology due to its appropriateness for the nature of this study.

\section{Population of the study}

The population of the study consists of male and female basketball players of the university teams, participating in the HESF championship of the UAE universities for the 2018/2019 sports season. They are 156 male and female players, participants, and officially registered in the championship lists, representing 7 UAE universities and 13 teams in Abu Dhabi emirate.

\section{Sample of the study}

The sample of the study consists of 60 male and female players from 13 teams of 7 universities, participating in this championship, randomly selected at a percentage of $38.46 \%$. Table 1 shows the numbers of the male and female players of the universities, constituting the sample of the study.

Table 1. Shows the university names and number of players who represent the sample of the study of both sexes.

\begin{tabular}{|c|c|c|c|c|c|}
\hline SN & Sex & Teams & $\begin{array}{l}\text { Sample } \\
\text { Number }\end{array}$ & Percentage & Total \\
\hline 1 & \multirow{8}{*}{$\begin{array}{l}\text { Men's } \\
\text { Basketball }\end{array}$} & NYU Abu Dhabi - V & 4 & $33.3 \%$ & \multirow{8}{*}{$\begin{array}{l}\text { Male sample total } \\
N=39 \\
40.63 \%\end{array}$} \\
\hline 2 & & NYU Abu Dhabi - JV & 5 & $41.66 \%$ & \\
\hline 3 & & \begin{tabular}{|l} 
UAE University \\
\end{tabular} & 6 & $50 \%$ & \\
\hline 4 & & Abu Dhabi University & 5 & $41.66 \%$ & \\
\hline 5 & & Khalifa University & 5 & $41.66 \%$ & \\
\hline 6 & & \begin{tabular}{|l} 
Zayed University \\
\end{tabular} & 4 & $33.3 \%$ & \\
\hline 7 & & \begin{tabular}{|l} 
Paris Sorbonne \\
\end{tabular} & 6 & $50 \%$ & \\
\hline 8 & & \begin{tabular}{|l} 
HCT - Abu Dhabi Men's \\
\end{tabular} & 4 & $33.3 \%$ & \\
\hline 9 & \multirow{6}{*}{$\begin{array}{l}\text { Women's } \\
\text { Basketball }\end{array}$} & UAE University & 3 & $25 \%$ & \multirow{6}{*}{$\begin{array}{l}\text { Female sample } \\
\text { total } \\
\mathrm{N}=21 \\
35 \%\end{array}$} \\
\hline 10 & & NYU Abu Dhabi & 4 & $33.3 \%$ & \\
\hline 11 & & Zayed University & 5 & $41.66 \%$ & \\
\hline 12 & & Abu Dhabi University & 4 & $33.3 \%$ & \\
\hline 13 & & Khalifa University & 5 & $41.66 \%$ & \\
\hline & & Total Sum & 60 & $50 \%$ & \\
\hline
\end{tabular}




\section{Procedures of the study}

Tool of the study

The Scale Assessing Leadership Behaviour of Coaches, designed by Mustafa Abu Zaid, consisting of 55 items that measure 8 sub-dimensions in the scale, was used to measure the leadership behaviour of a coach. The dimensions are:

The first dimension (Training and Instruction), second dimension (Social Recognition), third dimension (Motivation), fourth dimension (Equity), fifth dimension (Athletic Performance), sixth dimension (Autocratic Behaviour), seventh dimension (Participation and Democratic Behaviour) and eighth dimension (Attention to Health Aspects).

There are 5 levels of response before each item (Always, Often, Occasionally, Seldom and Never) to be answered by the players in accordance with the styles of their coaches. 7 items of them have negative answers, and these constitute the fourth dimension, and 48 items are positive. Appendix I.

\section{Pilot experiment}

This experiment was performed on 31/10/2019 on 6 male and female players from participants in different university teams, who were ruled out from the sample. During that period, how far players understood the Scale, how clear the instructions and paragraphs were, and how possible the potential difficulties could be overcome in preparation for the main application of the Scale were identified.

\section{Test validity and reliability coefficients of the tool}

\section{Validity}

The two scales have been verified for validity through finding the apparent validity of both by showing them to a group of experts and specialists.

\section{Reliability}

A reliability coefficient has been used in applying the test and reapplying it in an interval for a week to get the reliability coefficient of the Scale on a 6-player sample. This is called the standardization sample, which was ruled out from the study sample, with the correlation coefficient between the two applications (Pearson) considered, and it was 0.83 , a high indicator of the scale reliability.

\section{Evaluating the scale}

The scale is evaluated as follows:

- (Positive) Items in the dimension direction:

(Always: 5 points / Often: 4 points / Occasionally: 3 points / Seldom: 2 points / Never: one point).

- (Negative) Items against the dimension direction are evaluated as follows:

(Always: one point / Often: 2 points / Occasionally: 3 points / Seldom: 4 points / Never: 5 points).

Given that the total measurement score is 275 .

\section{Statistical means}

SPAS system has been used to find the following statistical means:

(Arithmetic mean, Standard deviation, Correlation coefficient T for one sample, Pearson correlation coefficient). 


\section{FINDINGS AND DISCUSSION}

Table 2. Percentage of the Scale dimensions in order.

\begin{tabular}{|l|l|l|l|}
\hline No. & Dimension & Percentage & Dimension Order \\
\hline 1 & (Training and Instruction) & $80.35 \%$ & Fifth \\
\hline 2 & (Social Recognition) & $78.18 \%$ & Third \\
\hline 3 & (Motivation) & $64.91 \%$ & Sixth \\
\hline 4 & (Equity) & $60.88 \%$ & Seventh \\
\hline 5 & (Athletic Performance) & $84.75 \%$ & Second \\
\hline 6 & (Dictatorial Behaviour) & $54.75 \%$ & Eighth \\
\hline 7 & (Participation and Democratic Behaviour) & $77.33 \%$ & Fourth \\
\hline 8 & (Attention to Health Aspects) & $86.77 \%$ & First \\
\hline
\end{tabular}

Table 2 shows the percentages and order of the Scale dimensions, which was answered by the players, subjects of the sample.

Looking at Table 3, it can be observed that the total score, frequencies and the percentages the sample subjects' answers to the items of the first dimension of the Scale, Training and Instruction, consisting of 18 items, are all in the positive direction. The total score of this dimension is 5400 points. Through its answers, the study sample got 4339 points, with a percentage of $80.35 \%$, which is high. This, according to the researchers, is because the sample subjects provided positive answers about their coaches, who had the characteristics of that dimension; for them a coach illustrates clearly and in detail the preparation and the implementation of the game plans during training and competition. The researchers also attribute these results to the keenness of the coach on training players during the training units using scientific methods, and the coach's ability to detect the weaknesses of rival players. A coach also contributes, to a great extent, to correcting the performance mistakes that players exhibit in matches and focuses on the technical, skill and planning aspects. These findings are in line with Doherty \& Danylchuck (1996), Riemer \& Chelladurai (1995) and Qaryouti (2000) in that a successful leader is one who can gain the collaboration of his co-workers, achieve harmony among them and persuade them to accomplish their goals.

Table (4) indicates that the total score, frequencies and the percentages of the sample subjects' answers to the items of the second dimension of the Scale, Social Recognition, consisting of 9 items, are all in the positive direction. As shown in the table, the total score of this dimension is 2700 . Through its answers, the study sample got 2111 points, with a percentage of $78.18 \%$, which is a very high percentage. According to the researchers, this is because the sample subjects had positive answers about their coaches beyond the scope of the playfield and their coaches had the characteristics of that dimension. For them, a coach was keen to have a good relationship with the players outside the playfield, and he dealt with them as a brother and faithful friend. The researchers also attribute these results to the coach's keenness on maintaining a relation with the players based on mutual respect and openness until the end of the training season. The study is consistent with Altahayneh (2003) and Shallafah (1993) in the findings illustrating that democratic leadership depends, in the first place, on interpersonal relations between a leader and his followers, and on engaging the followers in problem solving and decision making. 
Table 3. Results of the sample answers to the items of dimension one (Training and Instruction). Total score of the quantitative dimension $=5400$, Total score of the sample in the dimension $=4339$, Percentage $=80.35 \%$.

\begin{tabular}{|c|c|c|c|c|c|c|c|c|c|c|c|c|c|c|c|c|}
\hline \multirow[b]{2}{*}{ SN } & \multirow[b]{2}{*}{$\begin{array}{l}\text { Item } \\
\text { No. }\end{array}$} & \multicolumn{3}{|c|}{ Always } & \multicolumn{3}{|c|}{ Often } & \multicolumn{3}{|c|}{ Occasionally } & \multicolumn{3}{|c|}{ Seldom } & \multicolumn{3}{|c|}{ Never } \\
\hline & & $\begin{array}{l}\text { Total } \\
\text { Score }\end{array}$ & Frequency & $\%$ & $\begin{array}{l}\text { Total } \\
\text { Score }\end{array}$ & Frequency & $\%$ & $\begin{array}{l}\text { Total } \\
\text { Score }\end{array}$ & Frequency & $\%$ & $\begin{array}{l}\text { Total } \\
\text { Score }\end{array}$ & Frequency & $\%$ & $\begin{array}{l}\text { Total } \\
\text { Score }\end{array}$ & Frequency & $\%$ \\
\hline 1 & 28 & 115 & 23 & $38.33 \%$ & 80 & 20 & $33.33 \%$ & 39 & 13 & $21.67 \%$ & 8 & 4 & $6.67 \%$ & 0 & 0 & $0 \%$ \\
\hline 2 & 30 & 120 & 24 & $40 \%$ & 64 & 16 & $26.67 \%$ & 54 & 18 & $30 \%$ & 4 & 2 & $3.33 \%$ & 0 & 0 & $0 \%$ \\
\hline 3 & 32 & 145 & 29 & $48.33 \%$ & 84 & 21 & $35 \%$ & 21 & 17 & $11.67 \%$ & 4 & 2 & $3.33 \%$ & 2 & 1 & $1.67 \%$ \\
\hline 4 & 35 & 115 & 23 & $38.33 \%$ & 92 & 23 & $38.33 \%$ & 36 & 12 & $20 \%$ & 4 & 2 & $3.33 \%$ & 2 & 2 & $3.33 \%$ \\
\hline 5 & 50 & 155 & 31 & $51.67 \%$ & 56 & 14 & $23.33 \%$ & 36 & 12 & $20 \%$ & 6 & 3 & $5 \%$ & 0 & 0 & $0 \%$ \\
\hline 6 & 12 & 85 & 17 & $28.33 \%$ & 84 & 21 & $35 \%$ & 60 & 20 & $33.33 \%$ & 2 & 1 & $1.67 \%$ & 1 & 1 & $1.67 \%$ \\
\hline 7 & 55 & 90 & 18 & $30 \%$ & 92 & 23 & $38.33 \%$ & 42 & 14 & $23.33 \%$ & 6 & 3 & $5 \%$ & 2 & 2 & $3.33 \%$ \\
\hline 8 & 3 & 210 & 42 & $70 \%$ & 40 & 10 & $16.67 \%$ & 21 & 7 & $11.67 \%$ & 2 & 1 & $1.67 \%$ & 0 & 0 & $0 \%$ \\
\hline 9 & 7 & 160 & 32 & $53.33 \%$ & 72 & 18 & $30 \%$ & 27 & 9 & $15 \%$ & 2 & 1 & $1.67 \%$ & 0 & 0 & $0 \%$ \\
\hline 10 & 52 & 105 & 21 & $35 \%$ & 92 & 23 & $38.33 \%$ & 39 & 13 & $21.67 \%$ & 4 & 2 & $3.33 \%$ & 1 & 1 & $1.67 \%$ \\
\hline 11 & 16 & 150 & 30 & $50 \%$ & 72 & 18 & $30 \%$ & 30 & 10 & $16.67 \%$ & 2 & 1 & $1.67 \%$ & 2 & 1 & $1.67 \%$ \\
\hline 12 & 38 & 110 & 22 & $36.67 \%$ & 92 & 23 & $38.33 \%$ & 36 & 12 & $20 \%$ & 2 & 1 & $1.67 \%$ & 0 & 2 & $3.33 \%$ \\
\hline 13 & 43 & 160 & 32 & $53.33 \%$ & 64 & 16 & $62.67 \%$ & 27 & 9 & $15 \%$ & 6 & 3 & $5 \%$ & 1 & 0 & $0 \%$ \\
\hline 14 & 45 & 10 & 32 & $53.33 \%$ & 52 & 13 & $21.67 \%$ & 36 & 12 & $20 \%$ & 4 & 2 & $3.33 \%$ & 0 & 1 & $1.67 \%$ \\
\hline 15 & 49 & 145 & 29 & $48.33 \%$ & 72 & 18 & $30 \%$ & 33 & 11 & $18.33 \%$ & 8 & 4 & $6.67 \%$ & 0 & 0 & $0 \%$ \\
\hline 16 & 17 & 80 & 16 & $26.67 \%$ & 10 & 27 & $45 \%$ & 45 & 15 & $25 \%$ & 2 & 1 & $1.67 \%$ & 1 & 1 & $1.67 \%$ \\
\hline 17 & 21 & 125 & 25 & $41.67 \%$ & 76 & 18 & $30 \%$ & 30 & 10 & $16.67 \%$ & 8 & 4 & $6.67 \%$ & 2 & 2 & $3.23 \%$ \\
\hline 18 & 25 & 70 & 14 & $23.33 \%$ & 80 & 20 & $33.33 \%$ & 48 & 16 & $26.67 \%$ & 16 & 8 & $13.33 \%$ & 2 & 2 & $3.23 \%$ \\
\hline
\end{tabular}

Table 4. Results of the sample answers to the items of dimension two (Social Recognition). Total score of the quantitative dimension $=2700$, Total score of the sample in the dimension $=2111$, Percentage $=78.18 \%$.

\begin{tabular}{|c|c|c|c|c|c|c|c|c|c|c|c|c|c|c|c|c|}
\hline \multirow[b]{2}{*}{ SN } & \multirow[b]{2}{*}{$\begin{array}{c}\text { Item } \\
\text { No. }\end{array}$} & \multicolumn{3}{|c|}{ Always } & \multicolumn{3}{|c|}{ Often } & \multicolumn{3}{|c|}{ Occasionally } & \multicolumn{3}{|c|}{ Seldom } & \multicolumn{3}{|c|}{ Never } \\
\hline & & $\begin{array}{l}\text { Total } \\
\text { Score }\end{array}$ & Frequency & $\%$ & $\begin{array}{l}\text { Total } \\
\text { Score }\end{array}$ & Frequency & $\%$ & $\begin{array}{l}\text { Total } \\
\text { Score }\end{array}$ & Frequency & $\%$ & $\begin{array}{l}\text { Total } \\
\text { Score }\end{array}$ & Frequency & $\%$ & $\begin{array}{l}\text { Total } \\
\text { Score }\end{array}$ & Frequency & $\%$ \\
\hline 1 & 24 & 100 & 20 & $33.33 \%$ & 100 & 25 & $41.67 \%$ & 27 & 9 & $15 \%$ & 8 & 4 & $6.67 \%$ & 2 & 2 & $3.33 \%$ \\
\hline 2 & 39 & 155 & 31 & $51.67 \%$ & 68 & 17 & $28.33 \%$ & 27 & 9 & $15 \%$ & 2 & 1 & $1.67 \%$ & 2 & 2 & $3.33 \%$ \\
\hline 3 & 8 & 181 & 36 & $60 \%$ & 44 & 11 & $18.33 \%$ & 24 & 8 & $13.33 \%$ & 6 & 3 & $5 \%$ & 2 & 2 & $3.33 \%$ \\
\hline 4 & 44 & 140 & 28 & $46.67 \%$ & 76 & 19 & $31.67 \%$ & 33 & 11 & $18.33 \%$ & 2 & 1 & $1.67 \%$ & 1 & 1 & $1.67 \%$ \\
\hline 5 & 45 & 190 & 38 & $36.63 \%$ & 28 & 7 & $11.67 \%$ & 30 & 10 & $16.67 \%$ & 10 & 5 & $8.33 \%$ & 0 & 0 & $0 \%$ \\
\hline 6 & 48 & 160 & 32 & $35.33 \%$ & 64 & 16 & $26.67 \%$ & 12 & 7 & $11.67 \%$ & 10 & 5 & $8.33 \%$ & 0 & 0 & $0 \%$ \\
\hline 7 & 46 & 35 & 7 & $11.67 \%$ & 24 & 16 & $26.67 \%$ & 21 & 7 & $11.67 \%$ & 10 & 5 & $8.33 \%$ & 0 & 0 & $0 \%$ \\
\hline 8 & 2 & 212 & 42 & $70 \%$ & 56 & 14 & $23.33 \%$ & 9 & 3 & $5 \%$ & 2 & 1 & $1.67 \%$ & 0 & 0 & $0 \%$ \\
\hline 9 & 14 & 115 & 23 & $38.33 \%$ & 80 & 20 & $33.33 \%$ & 33 & 11 & $18.33 \%$ & 8 & 4 & $6.67 \%$ & 2 & 2 & $3.33 \%$ \\
\hline
\end{tabular}

VOLUME $15 \mid$ Proc2 $|2020|$ S398 
Table 5. Results of the sample answers to the items of dimension three (Motivation). Total score of the quantitative dimension $=2400$, Total score of the sample in the dimension $=1558$, Percentage $=64.91 \%$

\begin{tabular}{|c|c|c|c|c|c|c|c|c|c|c|c|c|c|c|c|c|}
\hline \multirow[b]{2}{*}{ SN } & \multirow[b]{2}{*}{$\begin{array}{l}\text { Item } \\
\text { No. }\end{array}$} & \multicolumn{3}{|c|}{ Always } & \multicolumn{3}{|c|}{ Often } & \multicolumn{3}{|c|}{ Occasionally } & \multicolumn{3}{|c|}{ Seldom } & \multicolumn{3}{|c|}{ Never } \\
\hline & & $\begin{array}{l}\text { Total } \\
\text { Score }\end{array}$ & Frequency & $\%$ & $\begin{array}{l}\text { Total } \\
\text { Score }\end{array}$ & Frequency & $\%$ & $\begin{array}{l}\text { Total } \\
\text { Score }\end{array}$ & Frequency & $\%$ & $\begin{array}{l}\text { Total } \\
\text { Score }\end{array}$ & Frequency & $\%$ & $\begin{array}{l}\text { Total } \\
\text { Score }\end{array}$ & Frequency & $\%$ \\
\hline 1 & 47 & 106 & 21 & $35 \%$ & 84 & 21 & $35 \%$ & 33 & 11 & $18.33 \%$ & 12 & 6 & $10 \%$ & 1 & 1 & $1.67 \%$ \\
\hline 2 & 40 & 99 & 20 & $33.33 \%$ & 80 & 20 & $33.33 \%$ & 42 & 14 & $23.33 \%$ & 6 & 3 & $5 \%$ & 3 & 3 & $5 \%$ \\
\hline 3 & 4 & 65 & 13 & $21.67 \%$ & 100 & 25 & $41.67 \%$ & 42 & 14 & $23.33 \%$ & 6 & 3 & $5 \%$ & 5 & 5 & $8.33 \%$ \\
\hline 4 & 11 & 106 & 21 & $35 \%$ & 88 & 22 & $36.67 \%$ & 36 & 12 & $20 \%$ & 6 & 3 & $5 \%$ & 2 & 2 & $3.33 \%$ \\
\hline 5 & 22 & 140 & 28 & $46.67 \%$ & 48 & 12 & $20 \%$ & 30 & 10 & $16.67 \%$ & 12 & 6 & $10 \%$ & 4 & 4 & $6.67 \%$ \\
\hline 6 & 53 & 52 & 10 & $16.67 \%$ & 60 & 15 & $25 \%$ & 30 & 10 & $16.67 \%$ & 28 & 14 & $23.33 \%$ & 11 & 11 & $18.33 \%$ \\
\hline 7 & 33 & 66 & 13 & $21.67 \%$ & 88 & 22 & $36.67 \%$ & 60 & 20 & $33.33 \%$ & 4 & 2 & $3.33 \%$ & 3 & 3 & $5 \%$ \\
\hline
\end{tabular}

Table 6. Results of the sample answers to the items of dimension four (Equity). Total score of the quantitative dimension $=1800$, Total score 1of the sample in the dimension $=1070$, Percentage $=59.44 \%$.

\begin{tabular}{|c|c|c|c|c|c|c|c|c|c|c|c|c|c|c|c|c|}
\hline \multirow[b]{2}{*}{ SN } & \multirow[b]{2}{*}{$\begin{array}{l}\text { Item } \\
\text { No. }\end{array}$} & \multicolumn{3}{|c|}{ Always } & \multicolumn{3}{|c|}{ Often } & \multicolumn{3}{|c|}{ Occasionally } & \multicolumn{3}{|c|}{ Seldom } & \multicolumn{3}{|c|}{ Never } \\
\hline & & $\begin{array}{l}\text { Total } \\
\text { Score }\end{array}$ & Frequency & $\%$ & $\begin{array}{l}\text { Total } \\
\text { Score }\end{array}$ & Frequency & $\%$ & $\begin{array}{l}\text { Total } \\
\text { Score }\end{array}$ & Frequency & $\%$ & $\begin{array}{l}\text { Total } \\
\text { Score }\end{array}$ & Frequency & $\%$ & $\begin{array}{l}\text { Total } \\
\text { Score }\end{array}$ & Frequency & $\%$ \\
\hline 1 & 26 & 26 & 5 & $8.33 \%$ & 28 & 7 & $11.67 \%$ & 54 & 18 & $30 \%$ & 32 & 16 & $26.67 \%$ & 14 & 14 & $23.33 \%$ \\
\hline 2 & 42 & 42 & 8 & $13.33 \%$ & 60 & 15 & $25 \%$ & 69 & 32 & $38.33 \%$ & 14 & 7 & $11.67 \%$ & 7 & 7 & $11.67 \%$ \\
\hline 3 & 51 & 20 & 4 & $6.67 \%$ & 52 & 13 & $21.67 \%$ & 45 & 15 & $25 \%$ & 22 & 11 & $18.33 \%$ & 17 & 17 & $28.33 \%$ \\
\hline 4 & 5 & 26 & 5 & $8.33 \%$ & 68 & 17 & $28.33 \%$ & 72 & 24 & $40 \%$ & 20 & 10 & $16.67 \%$ & 4 & 4 & $6.67 \%$ \\
\hline 5 & 9 & 61 & 12 & $20 \%$ & 72 & 18 & $30 \%$ & 30 & 10 & $16.67 \%$ & 30 & 15 & $25 \%$ & 5 & 5 & $8.33 \%$ \\
\hline 6 & 18 & 66 & 13 & $21.67 \%$ & 52 & 13 & $21.67 \%$ & 75 & 25 & $41.67 \%$ & 8 & 4 & $6.67 \%$ & 5 & 5 & $8.33 \%$ \\
\hline
\end{tabular}

Table 7. Results of the sample answers to the items of dimension five (Athletic performance). Total score of the quantitative dimension $=1200$, Total score of the sample in the dimension $=1017$, Percentage $-84.75 \%$.

\begin{tabular}{|c|c|c|c|c|c|c|c|c|c|c|c|c|c|c|c|c|}
\hline \multirow[b]{2}{*}{ SN } & \multirow{2}{*}{$\begin{array}{l}\text { Item } \\
\text { No. }\end{array}$} & \multicolumn{3}{|c|}{ Always } & \multicolumn{3}{|c|}{ Often } & \multicolumn{3}{|c|}{ Occasionally } & \multicolumn{3}{|c|}{ Seldom } & \multicolumn{3}{|c|}{ Never } \\
\hline & & $\begin{array}{l}\text { Total } \\
\text { Score }\end{array}$ & Frequency & $\%$ & $\begin{array}{l}\text { Total } \\
\text { Score }\end{array}$ & Frequency & $\%$ & $\begin{array}{l}\text { Total } \\
\text { Score }\end{array}$ & Frequency & $\%$ & $\begin{array}{l}\text { Total } \\
\text { Score }\end{array}$ & Frequency & $\%$ & $\begin{array}{l}\text { Total } \\
\text { Score }\end{array}$ & Frequency & $\%$ \\
\hline 1 & 15 & 184 & 36 & $60 \%$ & 64 & 16 & $27.67 \%$ & 9 & 3 & $5 \%$ & 6 & 3 & $5 \%$ & 2 & 2 & $3.34 \%$ \\
\hline 2 & 27 & 112 & 22 & $36.67 \%$ & 48 & 12 & $20 \%$ & 45 & 15 & $25 \%$ & 20 & 10 & $16.67 \%$ & 1 & 1 & $1.68 \%$ \\
\hline 3 & 10 & 191 & 39 & $65 \%$ & 60 & 15 & $25 \%$ & 12 & 4 & $6.67 \%$ & 4 & 2 & $3.33 \%$ & 0 & 0 & $0 \%$ \\
\hline 4 & 6 & 163 & 32 & $53.33 \%$ & 64 & 16 & $26.67 \%$ & 24 & 8 & $13.33 \%$ & 8 & 4 & $6.67 \%$ & 0 & 0 & $0 \%$ \\
\hline
\end{tabular}


Table 8. Results of the sample answers to the items of dimension six (Autocratic Behaviour). Total score of the quantitative dimension $=1200$, Total score of the sample in the dimension $=657$, Percentage $-54.75 \%$.

\begin{tabular}{|c|c|c|c|c|c|c|c|c|c|c|c|c|c|c|c|c|}
\hline \multirow[b]{2}{*}{$\begin{array}{l}\mathrm{S} \\
\mathrm{N}\end{array}$} & \multirow{2}{*}{$\begin{array}{c}\text { Ite } \\
\text { m } \\
\text { No. }\end{array}$} & \multicolumn{3}{|c|}{ Always } & \multicolumn{3}{|c|}{ Often } & \multicolumn{3}{|c|}{ Occasionally } & \multicolumn{3}{|c|}{ Seldom } & \multicolumn{3}{|c|}{ Never } \\
\hline & & $\begin{array}{l}\text { Total } \\
\text { Score }\end{array}$ & Frequency & $\%$ & $\begin{array}{l}\text { Total } \\
\text { Score }\end{array}$ & Frequency & $\%$ & $\begin{array}{l}\text { Total } \\
\text { Score }\end{array}$ & Frequency & $\%$ & $\begin{array}{l}\text { Total } \\
\text { Score }\end{array}$ & Frequency & $\%$ & $\begin{array}{l}\text { Total } \\
\text { Score }\end{array}$ & Frequency & $\%$ \\
\hline 1 & 23 & 31 & 7 & $10 \%$ & 24 & 6 & $10 \%$ & 63 & 21 & $35 \%$ & 40 & 20 & $33.33 \%$ & 7 & 7 & $11.67 \%$ \\
\hline 2 & 41 & 46 & 10 & $15 \%$ & 44 & 11 & $33.18 \%$ & 51 & 17 & $33.28 \%$ & 22 & 11 & $33.18 \%$ & 12 & 12 & $20 \%$ \\
\hline 3 & 13 & 31 & 7 & $10 \%$ & 48 & 12 & $20 \%$ & 48 & 16 & $67.26 \%$ & 36 & 18 & $30 \%$ & 8 & 8 & $33.13 \%$ \\
\hline 4 & 34 & 41 & 9 & $33.13 \%$ & 32 & 8 & $33.13 \%$ & 30 & 10 & $67.16 \%$ & 18 & 19 & $15 \%$ & 25 & 25 & $67.41 \%$ \\
\hline
\end{tabular}

Table 9. Results of the sample answers to the items of dimension seven (Participation and Democratic Behaviour). Total score of the quantitative dimension $=900$, Total score of the sample in the dimension $=696$, Percentage $-77.33 \%$.

\begin{tabular}{|c|c|c|c|c|c|c|c|c|c|c|c|c|c|c|c|c|}
\hline \multirow[b]{2}{*}{ SN } & \multirow[b]{2}{*}{$\begin{array}{l}\text { Item } \\
\text { No. }\end{array}$} & \multicolumn{3}{|c|}{ Always } & \multicolumn{3}{|c|}{ Often } & \multicolumn{3}{|c|}{ Occasionally } & \multicolumn{3}{|c|}{ Seldom } & \multicolumn{3}{|c|}{ Never } \\
\hline & & $\begin{array}{l}\text { Total } \\
\text { Score }\end{array}$ & Frequency & $\%$ & $\begin{array}{l}\text { Total } \\
\text { Score }\end{array}$ & Frequency & $\%$ & $\begin{array}{l}\text { Total } \\
\text { Score }\end{array}$ & Frequency & $\%$ & $\begin{array}{l}\text { Total } \\
\text { Score }\end{array}$ & Frequency & $\%$ & $\begin{array}{l}\text { Total } \\
\text { Score }\end{array}$ & Frequency & $\%$ \\
\hline 1 & 37 & 49 & 9 & $15 \%$ & 88 & 22 & $67.36 \%$ & 60 & 20 & $33.33 \%$ & 14 & 7 & $67.11 \%$ & 3 & 3 & $31.4 \%$ \\
\hline 2 & 3 & 198 & 40 & $67.66 \%$ & 44 & 11 & $33.18 \%$ & 24 & 8 & $33.31 \%$ & 2 & 1 & $67.1 \%$ & 0 & 0 & $0 \%$ \\
\hline 3 & 29 & 77 & 16 & $67.26 \%$ & 72 & 18 & $30 \%$ & 45 & 15 & $25 \%$ & 16 & 18 & $30 \%$ & 4 & 4 & $5.20 \%$ \\
\hline
\end{tabular}

Table 10. Results of the sample answers to the items of dimension eight (Attention to Health Aspects). Total score of the quantitative dimension $=900$, Total score of the sample in the dimension $=781$, Percentage $-86.77 \%$.

\begin{tabular}{|c|c|c|c|c|c|c|c|c|c|c|c|c|c|c|c|c|}
\hline \multirow[b]{2}{*}{ SN } & \multirow[b]{2}{*}{$\begin{array}{l}\text { Item } \\
\text { No. }\end{array}$} & \multicolumn{3}{|c|}{ Always } & \multicolumn{3}{|c|}{ Often } & \multicolumn{3}{|c|}{ Occasionally } & \multicolumn{3}{|c|}{ Seldom } & \multicolumn{3}{|c|}{ Never } \\
\hline & & $\begin{array}{l}\text { Total } \\
\text { Score }\end{array}$ & Frequency & $\%$ & $\begin{array}{l}\text { Total } \\
\text { Score }\end{array}$ & Frequency & $\%$ & $\begin{array}{l}\text { Total } \\
\text { Score }\end{array}$ & Frequency & $\%$ & $\begin{array}{l}\text { Total } \\
\text { Score }\end{array}$ & Frequency & $\%$ & $\begin{array}{l}\text { Total } \\
\text { Score }\end{array}$ & Frequency & $\%$ \\
\hline 1 & 31 & 197 & 41 & $65 \%$ & 40 & 10 & $1.67 \%$ & 21 & 7 & $11.67 \%$ & 4 & 2 & $3.31 \%$ & 2 & 2 & $3.31 \%$ \\
\hline 2 & 1 & 167 & 34 & $55 \%$ & 52 & 13 & $21.67 \%$ & 39 & 13 & $21.67 \%$ & 2 & 1 & $1.60 \%$ & 0 & 0 & $0 \%$ \\
\hline 3 & 19 & 151 & 29 & $50 \%$ & 76 & 19 & $31.66 \%$ & 24 & 8 & $13.33 \%$ & 6 & 3 & $5 \%$ & 0 & 0 & $0 \%$ \\
\hline
\end{tabular}


Table (5) indicates that the total score, frequencies and the percentages of the sample subjects' answers to the items of the third dimension of the Scale, Motivation, consisting of 7 items, are all in the positive direction. As shown in the table, the total score of this dimension is 2400 . Through its answers, the sample got 1558 points, with a percentage of $64.91 \%$, which is a relatively average percentage. According to the researchers, this is because there are times when coaches neither pay a lot of heed nor give much importance to motivation due to the dullness and laziness, which coaches undergo and as a result of the work pressure. Yet, motivation is considerably significant for players. Some coaches do not attach high importance to the psychological aspect, which influences the players' progress, contribution and performance in training and competition, and thus results in a lower professional level of the players. However, most studies emphasize the importance of the psychological aspect, psychological preparation and motivation due to their great significance for the player's performance and emotions, and therefore emotional stimulation, which becomes reflected in their level as well as skill and professional performance, as underlined by Allawi (2005). Whenever working with athletes, a coach should work on helping them acquire the behavioural characteristics and attitudes that can only be retrieved by motivation, practice and experience.

Table (6) shows that the total score, frequencies and the percentages of the sample subjects' answers to the items of the fourth dimension of the Scale, Equity, consisting of 6 items, are all in the negative direction. As shown in the table, the total score of this dimension is 1800. Through its answers, the sample got 1070 points, with a percentage of $59.44 \%$, which is an average percentage. According to the researchers, this is due to the players' high awareness of the type of equity available to coaches as they deal with the members of a team as well as the equity work mechanism employed during the training and competition of players. Players believe that coaches in UAE university teams should bring equity to the team members, for players who are not treated fairly by their coaches do not participate with their university teams, especially that no one can force a student to represent his/her university, and distinguished students are content with their clubs, which support them and attends to their needs both financially and morally. Hence, the researchers believe that players have a high degree of awareness and ability to analyse and evaluate the degree of equity brought by their coaches to them and their fellow players in the same team.

Table (7) indicates that the total score, frequencies and the percentages of the sample subjects' answers to the items of the fifth dimension of the Scale, Athletic performance, consisting of 4 items, are all in the positive direction. As shown in the table, the total score of this dimension is 1200 . Through its answers, the sample got 1017 points, with a percentage of $84.75 \%$, which is significantly high. According to the researchers, this result shows a high confidence of players in their coaches, which results in high accumulative experiences for the players, and thus, directly influences the performance level of an individual player, a pair of players or the entire team in general. It also affects the players' ability to assess the athletic performance and their professional as well as mental abilities through their planning performance and thinking in addition to their various ways of performance, which promotes the players' confidence in their coaches and gives a strong impetus to the coaches. Additionally, this constitutes a motivation for coaches' self-realization before their players, universities and university officials, with these results being consistent with both Sheikhly (2000) and Essam (2002).

Table (8) indicates that the total score, frequencies and the percentages of the sample subjects' answers to the items of the sixth dimension of the Scale, Autocratic Behaviour, consisting of 4 items, are all in the positive direction. As shown in the table, the total score of this dimension is 1200 . Through its answers, the sample got 1017 points, with a percentage of $54.75 \%$. According to the researchers, this result is attributed to the coaches' tendency to autocracy and use of commands in treatment with the players in a way not convenient for their level and stage, as university students who have a certain sense of maturity, and who independently 
think and choose the way and plan proper for the competitions, and can adequately make decisions and shoulder responsibility. The researchers explain another reason for the results, i.e. coaches do not engage players in training units, neither do they listen to the players' opinions in the trainings or most of the time due to the players' preoccupation with the study and training in clubs. Therefore, meetings with coaches in universities become few, and accordingly coaches impose certain plans or methods upon the players in a dictatorial manner. These results are consistent with the results of Sriboon (2001), which showed that the dictatorial leadership behaviour was prevalent among team coaches in Thailand.

Table (9) shows that the total score, frequencies and the percentages of the sample subjects' answers to the items of the seventh dimension of the Scale, Participation and Democratic Behaviour, consisting of 3 items, are all in the positive direction. The researchers have found that the total score of this dimension is 900 . Through the answers, the sample got 696 points, representing $77.33 \%$, which is a high percentage. According to the researchers, the reason for this result is the players' praise of their coaches' agreeable treatment inside the training units, sports competition and sports life. In other words, the relation between players and coaches was good, with coaches treating players in a democratic, participative manner, leaving them the freedom and independence of making decisions, applying the exercises as well as various plans and taking responsibility. Such a style will certainly affect the positive reaction of the players, whether in trainings or competitions, given that they are university students, with whose mental level such style is appropriate, particularly at this stage. This study is consistent with Altahayneh (2003) and Allawi (2005) in assuming that in sports a coach can be deemed a leader, since his/her training duties oblige him/her to instruct and guide the players, attempt to influence their behaviour, help them upgrade their physical; skill and planning abilities and develop their personal characteristics, in addition to his/her significant role in achieving the social interaction among players, which causes solidarity of the team as a whole. The study is also in line with Riemer and Chelladurai's (1995) study, which showed that USA football fullbacks prefer the democratic method and social recognition.

Table (10) indicates that the total score, frequencies and the percentages of the sample subjects' answers to the items of the eighth dimension of the Scale, Attention to Health Aspects, consisting of 3 items, are all in the positive direction. As shown in the table, the total score of this dimension is 900 . Through its answers, the sample got 781 points, representing $86.77 \%$, which is a high percentage. According to the researchers, this result is attributed to the necessity for a coach to be attentive, especially at the university level, where most coaches are university professors, who, through their mental and educational level, can realize quite well that attention to health aspects has a direct and influential impact on the players' output as well as their skill and physical level. Therefore, players will achieve the levels and results desired from sports competition. They also understand that perfection is one of the health essentials and players' physical and health safety in the training units and even in competitions affect the abilities and levels of students or players at their universities or clubs as well as their self-confidence and preparation for the championships. The findings of the study are in line with Altahayneh (2003) in that the method of training, that is to say, the instructions, including attention to health aspects and health status of the players as well as the ways of protection from injuries, aims to enhance the players' performance by increasing guidance, devoting attention to training requirements and attempting to coordinate the performance of the team members.

\section{CONCLUSIONS}

In light of the findings and discussion, the researchers have concluded that:

1. Attention to health aspects, athletic performance as well as social and democratic recognition were the most common and most used methods by coaches of the UAE university teams. 
2. The autocratic style was the least used by coaches in the UAE university teams of basketball; it ranked last.

3. Motivation ranked low in the mind of coaches, as shown by their inattention to motivation in the UAE universities.

4. The principle of equity was not clearly established by coaches in the UAE universities in the opinion of university basketball players.

\section{RECOMMENDATIONS}

In light of the study conclusions, the researchers recommend that:

1. Coaches in UAE universities need to devote attention to motivation and equity, for they are very important elements in the training and social life of the players.

2. Coaches are encouraged to avoid the autocratic behaviour and should join the players in building the training units and tactical plans and assessing the self-performance.

3. Coaches in UAE universities need to pay heed to the democratic or hybrid method, in accordance with the training and competition situation, due to its suitability for the way of thinking of university students.

4. Findings of the study should be generalized to HESF and the federation concerned with the game.

5. Similar studies and comparative studies of other team sports need to be conducted, and the effectiveness of the Scale should be recognized.

Training courses and workshops for university-wide coaches should be held for the most important new methods of training and sports leadership.

\section{REFERENCES}

Abdul Karim, Mahmoud Hamdi Mohamed. (1996). Emotional Stimulation and its Relation with the Physiologic Variables and Skill Performance in Volleyball, Scientific Conference (Human Development between Challenges and Ambitions). Faculty of Physical Education for Men, Helwan University, Cairo.

Allawi, Mohamed Hassan, Ratib and Osama Kamel. (1999). Physical Education and Sports Psychology. Cairo, Dar El Fikr El Arabi.

Allawi, Muhammad Hassan and Radwan, Mohamed Nasr El-Din. (2000). Measurement by Physical Education and Sports Psychology., Cairo, Dar El Fikr El.

Allawi, Muhammad. (2002). Psychology of Sports Training and Competition. Cairo: Dar El Fikr El Arabi.

Allawi, Muhammad Hassan, 2005. The Psychology of Sports Leadership, Second Edition, Dar Al Kitab wal Nashr, Cairo, Arab Republic of Egypt.

Alois, Taha. (1997). Sports Psychology: Applied Concepts. (2nd Ed). Cairo, Dar El Fikr El Arabi.

Alsheikhly, Saad et al. (2000). A Comparison between the Levels of Emotional Response of Players in Some Youth Team and Individual Sports, College of Education Journal, Volume (15), Issue (2), Baghdad University, Iraq pp 146-231.

Alsaleh, Majed Selim. (2017). Emotional Balance for Female Basketball Players in Arab Clubs and its Relation with the Motivation for Accomplishment. Volume of the Third International Sports Scientific Conference in the Science and Technologies of Physical and Sports Activities, Tunisia.

Altahayneh, Z. L. (2003). The Effects of Coaches' Behaviors and Burnout on the Satisfaction and Burnout of Athletes, Unpublished Doctoral Dissertation. The Florida State University, Tallahassee. 
Arab, Muhammad Jassam, Kazem and Musa Jawad. (2001). A Comparison of Emotional Response Levels among the Aged and the Youths in Boxing, Journal of Physical Education College. Issue 1. Diyala, Baqubah.

Badr, Mahmoud. (1973). Fundamentals and Methodologies of Scientific Research. Printing Agency, Kuwait.

Doherty, A. J. and Danylchuck, K. E. (1996). Transformational and Transactional Leadership in Interuniversity Athletic Management. Journal of Sport Management, 10 (3): 292-309. https://doi.org/10.1123/jsm.10.3.292

Dorothy,V. and Harris. (1984). The Athlete's Guide to Sport Psychology. New York, Leisure Press. PP 16.

Essam, Abdel-Reda. ( 2002). Psychological Security and Its Relation with the Basketball Players' Level of Emotional Stimulation. Unpublished Masters Dissertation, College of Physical Education. Mosul University.

Houari, Sayed. (1982). The Effective Manager: An Analytic Study of the Mangers Union. Ain Shams University, Cairo.

Issawi, Abdel Rahman Mohamed. (1991). Physiological Psychology: A Study in Explaining the Human Behavior. Beirut, Dar Al-Nahda for Publishing.

Jaber, Ramsey. (2010). How Common is the Competitive Behavior Phenomenon among Football Players in the Governorates of Gaza, An-Najah Journal, Volume (24), Issue (10), An-Najah University, Palestine, pp 2970-2988.

Khairi, Ahmed and Abdel Hamid, Jamal. (1975). Research Methodologies and Psychology. Dar Al-Ta'leef Press, Cairo.

Khoraybet, Resan. (1998). Important Theories in Sports Training. Amman, As-Sharq Publishing.

Klenk, Courtney A. (2006). Psychological Response to Injury, Recovery, and Social Support: A Survey of Athletes at an NCAA Division I University. Senior Honors Projects. Paper 9.

Qaryouti, Mohamed Qasem. (2000). Leadership Behavior: Studying the Individual and Group Human Behavior in Different Organizations. Amman, Dar Asshourouk for Publishing.

Mustafa, Ibrahim Yahya. (1991). Forms of Attention of Short-distance Swimmers: A Collection of Published Researches. College of Physical Education, University of Basrah, p. 169.

Ratib, Kamel. (1995). Sports Psychology: Concepts and Applications (1st Ed). Cairo, Dar Al-Fekr AlAraby, Egypt.

Riemer, H. A., and Chelladurai, P. (1995). Leadership and Satisfaction in Athletics. Journal of Sport and Exercise Psychology, 17 (3): 276-293. https://doi.org/10.1123/jsep.17.3.276

Rizk, Fouad. (1991). Relation between Manifestation of Emotional Characteristics and Manifestation of Attention of Physical Education Students, Journal of Science, Arts, Studies and Research, Volume Two, Issue Two. Helwan University, Egypt.

Samreen, Hani Jamil. (1995). Sources and Levels of Psychological Anxiety of Male and Female of Jordan's Mass Teams, Unpublished Masters Dissertation, College of Physical Education, University of Jordan, p. 7.

Shallafah, Shaker. (1993). The Relation between a Manager's Realization of His Own style and an Educator's Realization of that Style and the Impact of such a Relation upon the Level of Moral Spirit of Educators in the Public Secondary Schools of Greater Amman of the First and Second Municipalities. Unpublished Masters Dissertation, University of Jordan, Amman.

Sriboon, N. (2001). Coach Leadership Behaviors, Team Cohesion, and Athlete Satisfaction in Relation to the Performance of Athletes in the 1999 Rajabhat Games. Unpublished Doctoral Dissertation, The Florida State University, Tallahassee. 


\section{Appendix I.}

The final form of the study after the last modification:

Dear Player

Greetings

The researchers are conducting a study entitled:

(Distinguished Leadership Behaviours and Styles of Basketball Coaches in UAE Universities).

I should be grateful if you would fill in this form carefully and faithfully for the purposes of scientific research.

Therefore, please do read each item, and after having understood its meaning, answer directly with what personally applies to you, given that there are no wrong or right answers.

Tick $(\sqrt{ })$ in the place that applies to you before every item. Please leave no blank items in the Scale.

Please note that all the information shall be dealt with absolute confidentiality.

Sincerely,

The Researchers

\section{Personal Information:}

\begin{tabular}{|l|l|}
\hline Name & (Optional) \\
\hline Age / Height / Weight & (Years) $\quad(\mathrm{Cm}) \quad(\mathrm{Kg})$ \\
\hline Name of University & \\
\hline College & \\
\hline Academic Year & \\
\hline Training Age & \\
\hline
\end{tabular}

Tick $(\sqrt{ })$ before every statement in the place that applies to you

\begin{tabular}{|c|c|c|c|c|c|c|}
\hline SN & Items & Always & Often & Occasionally & Seldom & Never \\
\hline 1 & Pays attention to the health aspects of players. & & & & & \\
\hline 2 & $\begin{array}{l}\text { Keen on having a good relationship with the players } \\
\text { outside the court. }\end{array}$ & & & & & \\
\hline 3 & $\begin{array}{l}\text { Explains to the players in detail how to apply the } \\
\text { proposed game plan of a match. }\end{array}$ & & & & & \\
\hline 4 & $\begin{array}{l}\text { Works to provide an adequate transitional allowance } \\
\text { to the players. }\end{array}$ & & & & & \\
\hline 5 & $\begin{array}{l}\text { Tolerates with misconduct of the players who are } \\
\text { relied upon in matches. }\end{array}$ & & & & & \\
\hline 6 & $\begin{array}{l}\text { Cooperates with the administrative officials of the } \\
\text { team to provide the sports tools and devices useful for } \\
\text { the training. }\end{array}$ & & & & & \\
\hline 7 & $\begin{array}{l}\text { Players are being scientifically trained on the } \\
\text { proposed game plan of a match. }\end{array}$ & & & & & \\
\hline 8 & Treats the players as a big brother. & & & & & \\
\hline 9 & $\begin{array}{l}\text { Relies on a constant group of players, who represent } \\
\text { the team in each game. }\end{array}$ & & & & & \\
\hline 10 & Keen on providing the proper uniform for the players & & & & & \\
\hline
\end{tabular}




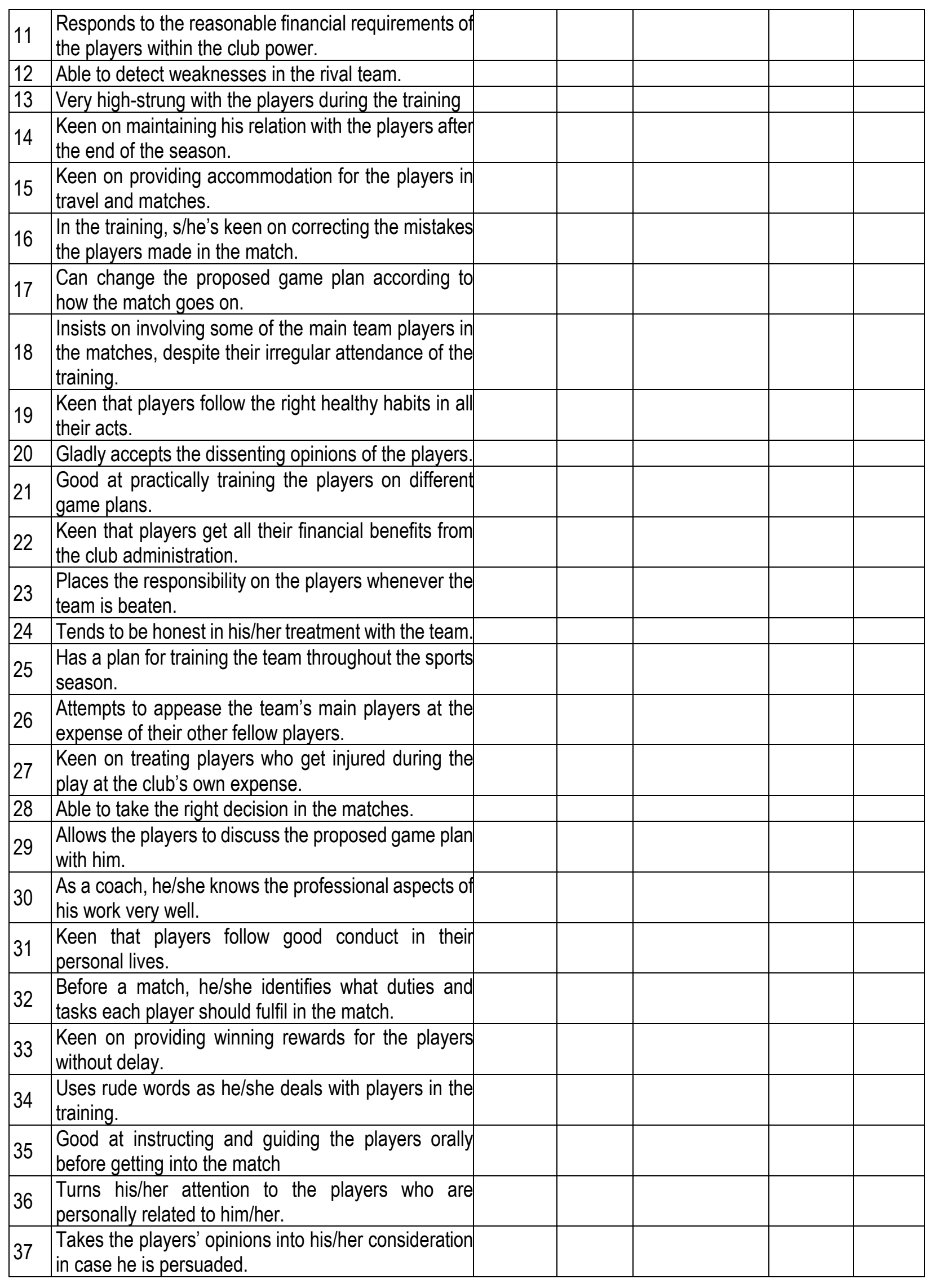




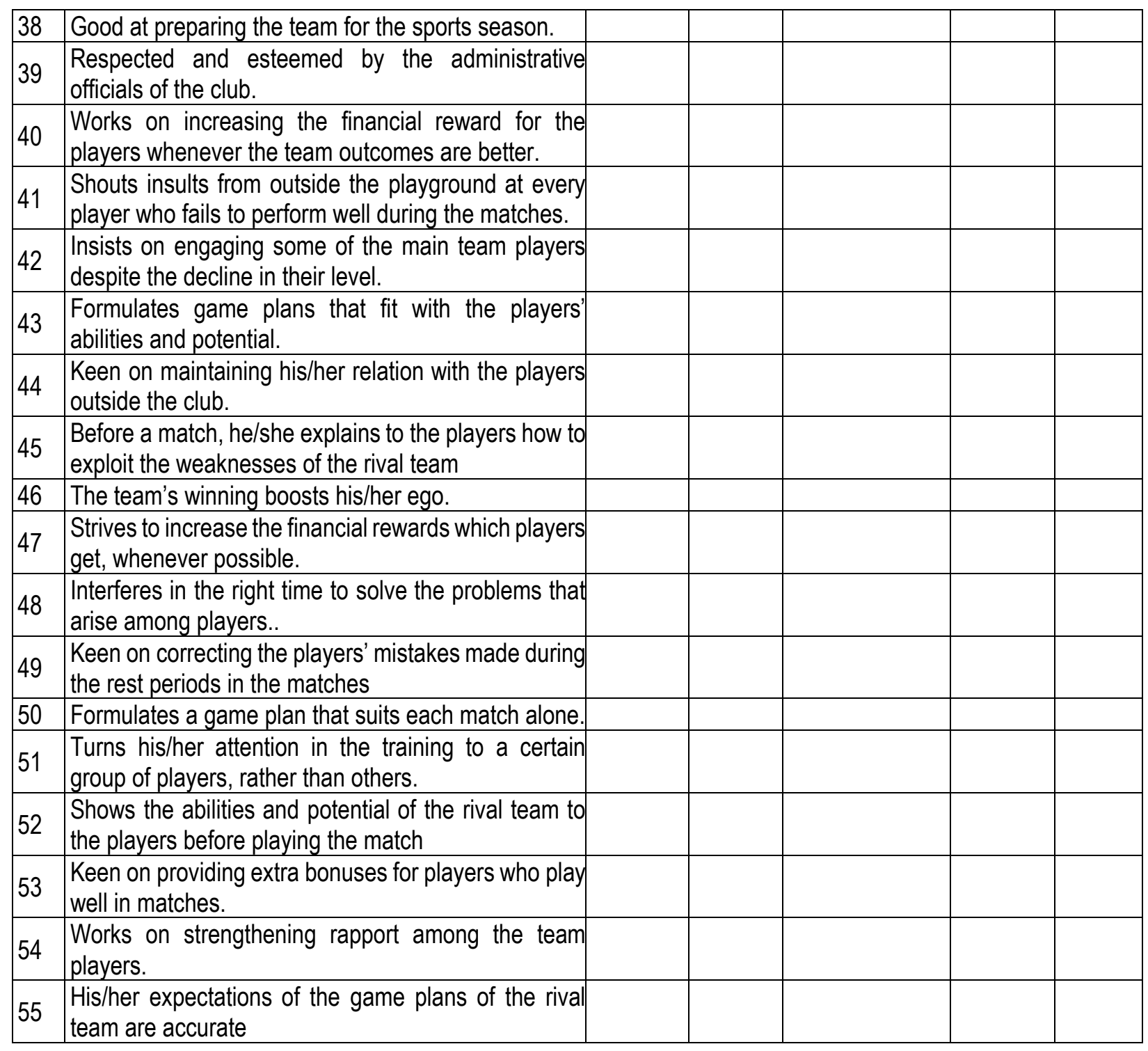

\section{(c) 7 (1) $\Theta$}

This work is licensed under a Attribution-NonCommercial-NoDerivatives 4.0 International (CC BY-NC-ND 4.0). 